\title{
Effects of long-term fluoxetine treatment on adrenergic plasticity in rat vas deferens
}

\author{
Cláudio Fontes Souza1,*, Lúcia Garcez-do-Carmo¹, Isaltino Marcelo Conceição², \\ Thalma Ariani Freitas², Roberto Frussa-Filho ${ }^{1}$
}

\author{
${ }^{1}$ Department of Pharmacology, Federal University of São Paulo, São Paulo, SP, Brazil, ${ }^{2}$ Laboratory of Pharmacology, Unit of \\ Mode of Toxin Action, Butantan Institute, São Paulo, SP, Brazil
}

\begin{abstract}
Chronic antidepressant administration increases neurotrophin levels in the central and peripheral nervous system, leading to an increase of neuronal sprouting, reestablishment of neural networks and neurotransmitter levels. Injured peripheral nerves regenerate at very slow rates. However, the recovery of the hypogastric nerve in rodents after injury is significantly improved with neurotrophin administration. Accordingly, our goal was to determine whether treatment with the antidepressant fluoxetine affects catecholamine levels and neuronal function, after surgical denervation of the rat vas deferens. Noradrenaline levels in the denervated vas deferens were higher in fluoxetine-treated animals than in the vehicle-treated group, as measured by high performance liquid chromatography. In functional studies of smooth muscle contraction, the responses induced by phenylephrine or ATP, as well as pre-synaptic $\alpha_{2}$-adrenoceptor reactivity, were not modified by chronic treatment with the antidepressant. However, the contraction mediated by neuronal release of noradrenaline induced by tyramine was increased on days 7 and 21 after denervation in rats treated with fluoxetine. These data indicate that fluoxetine can improve functional recovery after rat vas deferens denervation.
\end{abstract}

Uniterms: Fluoxetine/chronic administration/effects. Denervation. Antidepressants/long term use/ experimental study. Adrenergic neurotransmission. Noradrenaline/neuronal release.

A administração crônica de antidepressivos aumenta os níveis de neurotrofinas no sistema nervoso central, levando a um aumento da arborização neuronal, restabelecendo a rede neural e os níveis de neurotransmissores. Lesões do sistema nervoso periférico mostram uma regeneração muito lenta. Entretanto, a recuperação após a lesão do nervo hipogástrico em roedores é significativamente melhorada após a administração de neurotrofinas. Nesse sentido, nosso objetivo foi verificar se o tratamento com o antidepressivo, fluoxetina, interfere nos níveis de catecolaminas e na função neuronal, após a desnervação cirúrgica do ducto deferente de rato. Nos vasos deferentes desnervados, os níveis de catecolaminas nos grupos tratados com fluoxetina foram maiores que no grupo veículo, quantificados em cromatografia líquida de alta eficiência (CLAE). Nos estudos funcionais, a contração da musculatura lisa induzida pela fenilefrina ou pelo ATP, assim como a reatividade pré-sináptica $\alpha_{2}$-adrenérgica, não foram modificadas com o tratamento crônico de fluoxetina. Contudo, nas contrações mediadas pela liberação neuronal de norepinefrina induzida por tiramina, observou-se aumento da contração nos dias 7 e 21 após a desnevação em ratos tratados com fluoxetina. Esses dados indicam que a fluoxetina pode melhorar a recuperação funcional do vaso deferente de rato após a desnervação.

Unitermos: Fluoxetina/administração crônica/efeitos. Desnervação. Antidepressivos/uso contínuo/estudo experimental. Neurotransmissão adrenérgica. Norepinefrina/liberação neuronal

*Correspondence: C. F. Souza. Departmento de Famacologia, Universidade Federal de São Paulo. Rua Botucatu, 862, 04023-062 - São Paulo - SP, Brasil. E-mail: claudiofontes03@hotmail.com 


\section{INTRODUCTION}

Although the primary actions of antidepressants are usually related to an increase in monoamine levels in the central nervous system (CNS), the exact molecular mechanisms by which these agents exert their therapeutic effects are not well understood (Slattery, Hudson, Nutt, 2004). Several indications, such as brain imaging of post mortem animals and of depressed human patients show a correlation between depression and an axonal atrophy or reduction of the neuronal networks in many CNS areas (Slattery, Hudson, Nutt, 2004; Nestler et al., 2002). These neuronal alterations are reversed by chronic administration of antidepressants, which also induce an increase in axonal sprouting (Carlson et al., 2006; Santarelli et al., 2003). Neurotrophins such as nerve grow factor (NGF) and brain derivate neurotrophic factor (BDNF) regulate neuronal development and cell survival in the nervous system (Wang et al., 2008; McAllister, Katz, Lo, 1999). Chronic antidepressant administration induces an increase in levels of neurotrophic factors (Sofroniew, Howe, Mobley, 2001; Castrén, 2005; Kuipers, Bramham, 2006) and in the expression and activation of BDNF receptors in the hippocampus and frontal cortex of rodents (Russo-Neustadt et al., 2000; Balu et al., 2008). Chronic fluoxetine treatment (selective serotonin reuptake inhibitors) increases NGF levels in cerebral areas, such as the prefrontal cortex and hippocampus (Hassanzadeh, Hassanzadeh, 2009). Due to the fact that antidepressants increase neurotrophin levels in the CNS, it is speculated that this process could also occur in the peripheral nervous system (PNS), where neuronal regeneration after a lesion also depends on neurotrophic factors, mainly NGF. In the urogenital tract, which is rich in neurotrophin receptors (Keast, Kepper, 2001), chronic treatment with exogenous NGF facilitates autonomic nerve regrowth (Burgers et al., 1991) and induces an increase neuronal activity (Milner et al., 1995). The vas deferens is a urogenital organ with a high neuronal network density, formed in great part by sympathetic nerves (Batra, 1974; Wanigasekara, Kepper, Keast, 2003). Therefore, the aim of the present work was to determine whether chronic administration of fluoxetine increases noradrenaline levels in the denervated vas deferens, which could indicate an improvement in the functional recovery process after nerve injury.

\section{MATERIAL AND METHODS}

\section{Animals and surgical procedures}

Male Wistar rats, 5 months old, weighing between
$300-350 \mathrm{~g}$ and housed under standard conditions $\left(24{ }^{\circ} \mathrm{C}\right.$ and a controlled 12-h light/dark cycle), were used. All experimental procedures were approved by the Ethics Committee of the Federal University of São Paulo.

Surgical denervation of both vasa deferentia was performed according to Kasuya and colleagues (1969). Briefly, the rats were anesthetized by intraperitoneal injection of ketamine/xylazine, and through a suprapubic incision, the prostatic portion of the vas deferens was exposed. The serous coat of this prostatic region, where the deferential artery and the hypogastric plexus come in contact with the vas deferens, was carefully picked off from approximately $1 \mathrm{~cm}$ from the prostatic end. During this procedure, great care was taken to avoid injury to the vas deferens and the vascular tissue. Later, the vasa deferentia were put back in place and the incision was sutured. Sham-operated rats (controls for the denervated rats) were operated in parallel, under the same conditions as the denervated group, with the exception that no denervation was performed. The rats were euthanized by $\mathrm{CO}_{2}$ asphyxiation 7,21 and 28 days after the surgery. Both vasa deferentia were removed and prepared for in vitro contraction experiments or biochemical analysis.

\section{Treatment}

The rats were treated daily with fluoxetine $(10 \mathrm{mg} / \mathrm{kg}$ i.p.) or vehicle (saline with $1 \%$ dimethyl sulfoxide) for 11 days prior to surgery and up to $24 \mathrm{~h}$ before euthanasia.

\section{Contraction experiments (in vitro)}

\section{Tissues preparation}

The vasa deferentia from denervated or shamoperated animals, treated with fluoxetine or vehicle, were removed for in vitro contraction experiments. Whole organs were acclimated in $10-\mathrm{mL}$ chamber organ baths, containing a nutrient solution $(138 \mathrm{mM} \mathrm{NaCl}$; $5.7 \mathrm{mM} \mathrm{KCl} ; 1.8 \mathrm{mM} \mathrm{CaCl}_{2} ; 15.0 \mathrm{mM} \mathrm{NaHCO}_{3}$; $0.36 \mathrm{mM} \mathrm{NaHPO}_{4} ; 5.5 \mathrm{mM}$ dextrose) prepared in glass-distilled deionized water at $30{ }^{\circ} \mathrm{C}$ and constant aeration $\left(95 \% \mathrm{O}_{2}\right.$ and $\left.5 \% \mathrm{CO}_{2}\right)$. Isometric contractions of the smooth muscle were recorded on a physiograph (UGO-BASILE ${ }^{\circledR}$ MOD.7080) using an isometric transducer (UGO-BASILE ${ }^{\circledR}$ MOD.7006) under a resting tension of $1.0 \mathrm{~g}$. After a period of stabilization $(30 \mathrm{~min})$, the vas deferens was contracted by a single concentration of barium chloride $(0.01 \mathrm{M})$ to test the viability of the tissue. After achieving the maximal contraction, the tissue 
was washed out and the experimental protocols were started 30 min later.

Contractile response to the indirect adrenergic agonist, tyramine

The vas deferens was contracted by a single concentration of the indirect adrenergic agonist tyramine $(100 \mu \mathrm{M})$ until the maximal contraction was achieved.

\section{Contractile response to electrical stimulation (ES)}

The vas deferens was placed between two parallel platinum electrodes and an electrical field stimulation was performed with a Grass ${ }^{\circledR} \mathrm{S} 88$ stimulator ( $50 \mathrm{~V}$ supramaximal voltage, $3 \mathrm{~ms}$ duration, $10 \mathrm{~Hz}$ frequency). These electrical stimulation parameters induce only neuronal stimulation without direct muscle stimulation, since this contraction was inhibited by tetrodotoxin, as previously described in our laboratory (Santos et al., 2003). Only the phasic component of the contraction was considered.

\section{Analysis of pre-synaptic $\alpha_{2}$-adrenoceptor activity}

The vas deferens was electrically stimulated with a frequency of $0.05 \mathrm{~Hz}(50 \mathrm{~V}, 3 \mathrm{~ms})$. When the electrical twitch responses were stabilized, concentration-response curves were obtained for the $\alpha_{2}$-adrenoceptor agonist clonidine. $\mathrm{The}_{\mathrm{pIC}}$ parameter (negative logarithm of the concentration of clonidine that induces a 50\% inhibitory effect) was obtained.

\section{Analysis of post-synaptic reactivity}

Three cumulative concentration-response curves for the $\alpha_{1}$-adrenergic agonist phenylephrine were obtained at 30-min intervals. Afterwards, the contraction induced by a single concentration of ATP $(10 \mathrm{mM})$ was recorded. The parameters obtained were maximum effect $\left(\mathrm{E}_{\max }\right.$, in grams of tension) and $\mathrm{pD}_{2}$ (negative logarithm of the concentration of the agonist that produces $50 \%$ of the maximum effect) for phenylephrine.

\section{Biochemical analysis of noradrenaline content}

The vasa deferentia from denervated or shamoperated animals treated with fluoxetine or vehicle were removed for biochemical analysis to determine the noradrenaline content of the tissue (Conceição et al., 2005). Briefly, the vasa deferentia were homogenized in $0.4 \mathrm{~N}$ perchloric acid, containing $0.1 \%$ sodium metabisulfite. After centrifugation $\left(7000 \mathrm{xg}, 45 \mathrm{~min}, 4^{\circ} \mathrm{C}\right)$, the supernatant was aspirated and stored at $-80{ }^{\circ} \mathrm{C}$ until analyzed by high-performance liquid chromatography (HPLC) with electrochemical detection.

\section{Statistical analyses}

The results were expressed as the mean \pm standard error. The significance of differences between two means was evaluated using a two-tailed Student t-test. Treatment groups were compared using one-way analysis of variance (ANOVA) and a post-hoc analysis of differing groups was carried out using a Tukey-Kramer test. P less than 0.05 indicated a statistically significant deference between groups.

\section{Drugs}

Chemicals: adenosine 5'-triphosphate (ATP), clonidine hydrochloride, norepinephrine (L-arterenol bitartrate) and tyramine were from Sigma Chemical Co., USA; fluoxetine, from Farmasa, BR; phenylephrine (L-phenyl-ephrine hydrochloride) from RBI, USA; and barium chloride, from Merck, BR. Stock solutions of the drugs were prepared in distilled water, with the exception of norepinephrine and phenylephrine, which were dissolved in $0.01 \mathrm{~N} \mathrm{HCl}$. Fluoxetine was dissolved in $1 \%$ DMSO in deionized water.

\section{RESULTS}

\section{Influence of chronic fluoxetine treatment on the denervation and reinnervation profile of rat vas deferens}

The characterization of the denervation and reinnervation of rat vas deferens was obtained indirectly, using in vitro contraction experiments, or directly, by biochemical noradrenaline quantification.

\section{In vitro contraction experiments}

Neuronal viability and pre-synaptic and postsynaptic receptor reactivity were analyzed in shamoperated and denervated vas deferens obtained from rats chronically treated for 11 days prior to surgery, with fluoxetine $(10 \mathrm{mg} / \mathrm{kg} /$ day $)$ or vehicle. The in vitro contraction experiments were done on days 7,21 , and 28 after surgery. Neuronal viability was measured under conditions that promote neurotransmitter release, as contraction induced by the indirect adrenergic agonist tyramine or by electrical stimulation.

\section{Tyramine}

Figure 1a shows that the amplitude of the contraction induced by tyramine $(100 \mu \mathrm{M})$ was lower in all denervated 
groups, compared to the respective sham-operated groups, as expected. The lowest contraction was observed on day 7 , followed by a gradual and partial recovery of response through day 28. Considering the denervated groups, in the fluoxetine-treated denervated group, the amplitude of the contraction was greater than that of its respective vehicle-treated denervated group. Differences in the amplitude of contraction were significant on days 7 and day 21. No differences were noted in the amplitude of contraction in either the fluoxetine-treated or vehicletreated sham-operated groups. These results indicate that fluoxetine treatment can improve the contraction induced by tyramine in denervated vas deferens.

\section{Electrically evoked contractions}

The amplitude of the contraction induced by electrical field stimulation $(10 \mathrm{~Hz})$ in all groups is shown in Figure 1b. As observed with tyramine, in the denervated groups, the amplitude of the contraction was reduced at all time points tested compared to the respective sham-operated groups. The lowest contraction was observed on day 7 , followed by a partial recovery of response through day 28. In the fluoxetine-treated group, there was a tendency towards an increase in the amplitude of contraction, but no statistical differences were obtained when compared to the respective vehicletreated denervated group. In sham-operated groups, no differences were noted between the fluoxetine-treated and vehicle-treated groups.

\section{Post-synaptic and pre-synaptic receptor reactivity}

The increase in tyramine-induced contraction observed in the denervated groups after fluoxetine treatment could be due to an alteration, induced by fluoxetine, in the post-synaptic reactivity of the vas deferens. The postsynaptic reactivity of the tissue was studied using exogenous agonists to evaluate the adrenergic and purinergic component of contraction. After denervation, an expected super-sensitivity of the vas deferens to the $\alpha_{1}$-adrenergic agonist phenylephrine was observed, characterized by an increase in the $\mathrm{E}_{\max }$ (in the day 7 and day 28 groups) and by the leftward shift of the concentration-response curves (increase in $\mathrm{pD}_{2}$ value) compared to the respective shamoperated group (Table I). Chronic fluoxetine treatment did not induce any alteration in these parameters in either the sham or denervated group, when compared to the respective vehicle-treated group (Table I).

After denervation, an increase in the amplitude of exogenously applied ATP $(100 \mu \mathrm{M})$ was observed in some groups; however, fluoxetine treatment did not induce any differences in the responses when compared
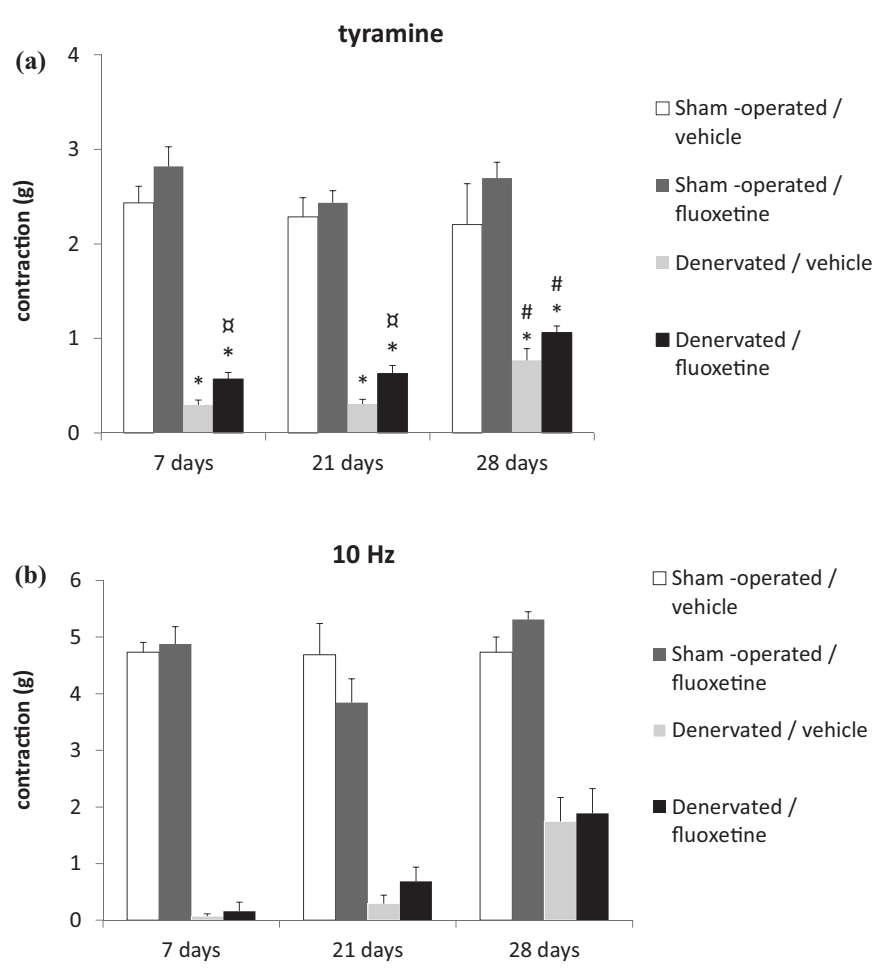

FIGURE 1. Histogram showing the maximum effect induced by (a) a single concentration of tyramine $(100 \mu \mathrm{M})$ and (b) electrical stimulation ( $3 \mathrm{~ms}, 50 \mathrm{~V}, 10 \mathrm{~Hz}$, phasic response) in rat vas deferens. The data are plotted for the sham-operated animals treated with vehicle (white), sham-operated animals treated with fluoxetine (dark gray), denervated animals treated with vehicle (light gray) and denervated animals treated with fluoxetine (black) for 7, 21 or 28 days after surgery. The bars represent the mean \pm S.E.M from four to six experiments. a, indicates a significant difference in relation to respective vehicle control group $(\mathrm{P}<0.05)$; *, indicates a significant difference in relation to the respective sham-operated group $(\mathrm{P}<0.05)$; \#, indicates a significant difference in relation to the respective day 7 group $(\mathrm{P}<0.05)$

to the respective vehicle-treated group (Table II). The pre-synaptic $\alpha_{2}$-adrenoceptor reactivity was also analyzed. The $\alpha_{2}$-adrenoceptor reactivity was evaluated by means of an inhibitory concentration-response curve to the $\alpha_{2}$-adrenoceptor agonist clonidine over the twitch contractions induced by electrical stimulation $(0.05 \mathrm{~Hz})$ in sham-operated vas deferens. No differences were noted in $\mathrm{pIC}_{50}$ value between the vehicle- $(9.09 \pm 0.10,8.89 \pm 0.07$, $8.77 \pm 0.18)$ and fluoxetine-treated $(8.96 \pm 0.07,8.97 \pm 0.03$, $8.74 \pm 0.04$ ) groups at all time points tested (respectively 7, 21 and 28 days).

\section{Noradrenaline quantification}

Noradrenaline levels in rat vas deferens were measured by HPLC with electrochemical detection 
TABLE I - $\mathrm{pD}_{2}$ and maximum amplitude of contraction $\left(\mathrm{E}_{\max }\right)$ in grams of tension from the phenylephrine concentration responsecurves obtained in vas deferens from sham-operated and denervated rats treated with vehicle or fluoxetine for 7, 21 and 28 days. Each value represents the mean \pm standard error from 9 to 12 experiments

\begin{tabular}{lcccc}
\hline & & \multicolumn{3}{c}{ Phenylephrine } \\
\cline { 3 - 5 } & & \multicolumn{3}{c}{$\mathbf{p D}_{\mathbf{2}}$} \\
\cline { 3 - 5 } sham-operated & vehicle & $\mathbf{7 ~ d a y s}$ & $\mathbf{2 1}$ days & $\mathbf{2 8 ~ d a y s}$ \\
\hline \multirow{2}{*}{ denervated } & fluoxetine & $6.78 \pm 0.08$ & $6.49 \pm 0.15$ & $6.56 \pm 0.05$ \\
& vehicle & $7.16 \pm 0.08^{*}$ & $7.28 \pm 0.13^{*}$ & $7.21 \pm 0.16^{*}$ \\
& fluoxetine & $7.09 \pm 0.08^{*}$ & $7.14 \pm 0.08^{*}$ & $7.06 \pm 0.12^{*}$ \\
\hline \multirow{2}{*}{ sham-operated } & & & $\mathbf{E}_{\max }(\mathbf{g})$ & $1.85 \pm 0.10$ \\
& vehicle & $1.80 \pm 0.19$ & $2.21 \pm 0.22$ & $2.06 \pm 0.16$ \\
\hline \multirow{2}{*}{ denervated } & fluoxetine & $2.23 \pm 0.19$ & $2.27 \pm 0.15$ & $2.47 \pm 0.27^{*}$ \\
& vehicle & $3.28 \pm 0.40^{*}$ & $2.32 \pm 0.29$ & $2.75 \pm 0.14$ \\
\hline
\end{tabular}

* indicates a significant difference in relation to the sham-operated group $(\mathrm{P}<0.05)$.

TABLE II - Maximum amplitude of contraction $\left(\mathrm{E}_{\max }\right)$, in grams of tension, from a single concentration of ATP $(100 \mu \mathrm{M})$ obtained in vas deferens from sham-operated and denervated rats treated with vehicle or fluoxetine for 7,21 and 28 days. Each value represents the mean \pm standard error of 5 to 8 experiments

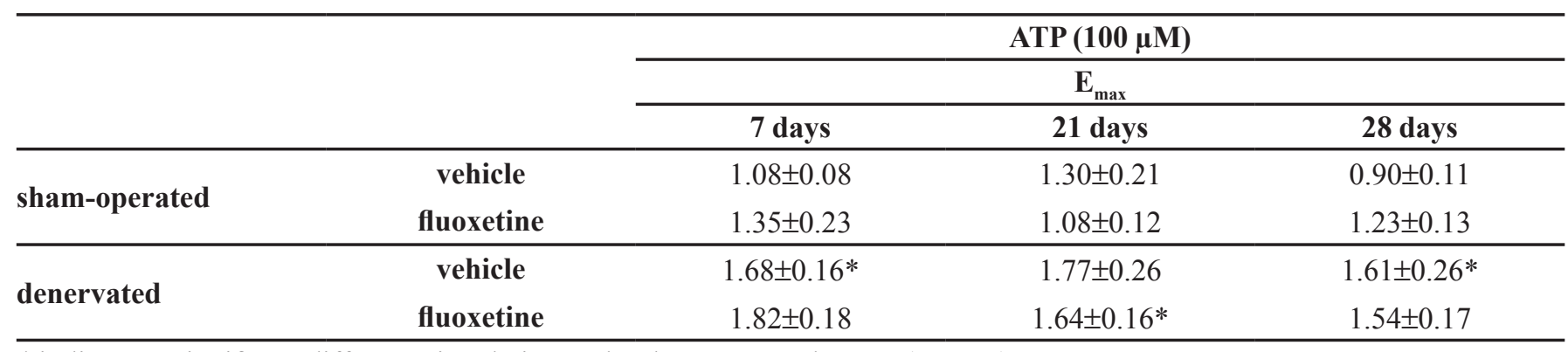

* indicates a significant difference in relation to the sham-operated group $(\mathrm{P}<0.05)$.

in sham-operated and denervated groups treated with fluoxetine or vehicle. Figure 2 shows that denervation caused a drastic decrease in noradrenaline levels, which was observed in both the treated and untreated groups, reaching the lowest concentration seven days after denervation, followed by a gradual recovery on days 21 and 28. Considering the denervated groups, noradrenaline levels were higher in the fluoxetinetreated group compared to the vehicle-treated group, at all time points studied. In the sham-operated group, noradrenaline levels were not altered by treatment with fluoxetine.

\section{DISCUSSION}

The main finding of the present study was that neurotransmitter levels were higher in denervated vas deferens from rats chronically treated with fluoxetine compared to denervated vehicle-treated duct. These results indicate that fluoxetine treatment could improve the process of reinnervation that normally occurs after vas deferens denervation.

Tissue neurotransmitter levels were evaluated by direct determination of tissue noradrenaline levels using electrochemical detection and indirect measurement by analyzing contractions induced by the indirect adrenergic agonist tyramine or by electrical stimulation. We observed that denervated vas deferens from animals treated with fluoxetine had an amplitude of contraction induced by tyramine that was greater than that observed in vehicle-treated denervated animals. Although this increase in tyramine contraction could indicate an increase in noradrenaline release, it could also be due to fluoxetine-induced modification of the reactivity 


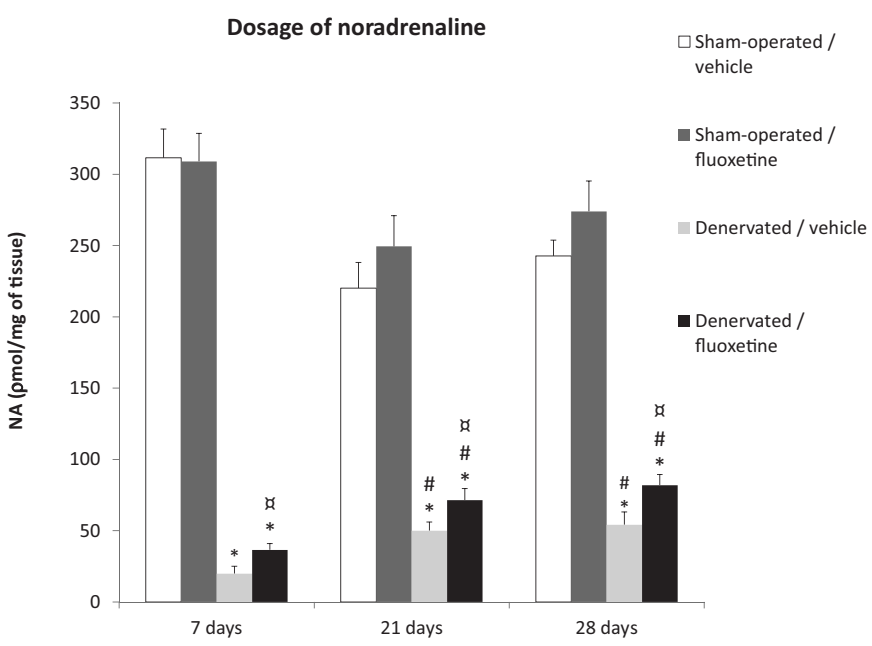

FIGURE 2 - Histogram showing the noradrenaline concentration (pmol/mg tissue) in vas deferens from sham-operated animals treated with vehicle (white), sham-operated animals treated with fluoxetine (dark gray), denervated animals treated with vehicle (light gray) or denervated animals treated with fluoxetine (black) on days 7,21 and 28 after surgery. The bars represent the mean \pm standard error of the mean of 10 experiments. $a$ indicates a significant difference in the relation to respective vehicle control group $(\mathrm{P}<0.05) ; *$ indicates a significant difference in relation to the respective sham-operated group $(\mathrm{P}<0.05)$; \# indicates a significant difference in relation to the respective day 7 group $(\mathrm{P}<0.05)$

of post-synaptic receptors or changes in the feedback mechanisms mediated by pre-synaptic receptors. However, control experiments with the $\alpha_{1}$-adrenergic agonist phenylephrine, purinergic agonist ATP and the $\alpha_{2}$-adrenergic agonist clonidine showed that the reactivity of the receptors associated with these agonists was not modified by fluoxetine treatment. As a result, the increase in tyramine-induced contraction could be due to a greater availability of noradrenaline. This hypothesis was confirmed by results obtained with electrochemical quantification of noradrenaline levels, where higher noradrenaline levels were observed in fluoxetine-treated denervated group compared to the vehicle-treated denervated group. In contrast, contractions induced indirectly by electrical stimulation were not significantly different, when comparing these two groups, although a tendency towards an increase in the amplitude of contraction was observed. The capacity of fluoxetine to increase neurotransmitter levels or neurotransmitter release in the experiments with tyramine and in the noradrenaline quantification was very slight, at the threshold of statistical validation. Therefore, one could argue that in the electrical stimulation studies, this weak fluoxetine action was not sufficient to induce a statistically significant effect. One possible explanation of this low effect of fluoxetine is the treatment protocol (dose and treatment duration). This protocol was based on published data in the literature. In CNS studies, chronic fluoxetine treatment (10 mg/kg/day, 21 days) induces an increase in NGF and BDNF levels in several brain regions (Molteni et al., 2006; Hassanzadeh, Hassanzadeh, 2009). Although the protocol used in our experiments followed one used to obtain effects in the CNS, this protocol may not be adequate for studies in the PNS. Another possibility is that the mechanism involved in the antidepressant-induced increase in neuronal viability is not as efficient in PNS as in CNS.

At the moment, it is not possible to determine the mechanism involved in this increase in noradrenaline levels in fluoxetine-treated denervated vas deferens. Several lines of evidence suggest that in the CNS the antidepressant-induced increase in neuronal viability is mediated by different signaling pathways, specifically through the activation of the transcriptional factor CREB and an increase in the synthesis of neurotrophic factors (Nibuya, Nestler, Duman, 1996; Altar, 1999). In the PNS, the antidepressant effects on neurotrophin levels are not well studied. Because the urogenital tract (and the vas deferens) is rich in NGF and neurotrophin receptors (Keast, Kepper, 2001), the effect of fluoxetine treatment could be mediated by the synthesis of NGF. Of note, the fluoxetine effects were obtained only in denervated vas deferens. Fluoxetine treatment did not affect shamoperated groups. These data indicate that fluoxetine can only increase noradrenaline levels during neuronal regeneration, thus suggesting that this effect occurs mainly in situations where the process of regeneration after a lesion has already been initiated.

In summary, our results indicate that chronic fluoxetine treatment could change plasticity during peripheral neuron regeneration, increasing catecholamine levels after denervation, where this could highlight a new potential therapeutic benefit of antidepressants.

\section{ACKNOWLEDGMENTS}

Thanks go to Teotila Reuter for technical assistance and CNPq for support of this work. Dr. A. Leyva (USA) helped with English editing of the manuscript.

\section{REFERENCES}

ALTAR, C.A. Neurotrophins and depression. Trends Pharmacol. Sci., v.20, n.2, p.59-61, 1999. 
BALU, D.T.; HOSHAW, B.A.; MALBERG, J.E.; ROSENZWEIG-LIPSON, S.; SCHECHTER, L.E.; LUCKI, I. Differential regulation of central BDNF protein levels by antidepressant and non-antidepressant drug treatments. Brain Res., v.1211, p.37-43, 2008.

BATRA, S.K. Sperm transport through vas deferens: review of hypotheses and suggestions for a quantitative model. Fertil Steril., v.25, n.2, p.186-202, 1974.

BURGERS, J.K.; NELSON, R.J.; QUINLAN, D.M.; WALSH, P.C. Nerve growth factor, nerve grafts and amniotic membrane grafts restore erectile function in rats. J. Urol., v.146, n.2, p.463-68, 1991.

CARLSON, P.J.; SINGH, J.B.; ZARATE, C.A.; DREVETS, W.C.; MANJI, H.K. Neural circuitry and neuroplasticity in mood disorders: insights for novel therapeutic targets. NeuroRx, v.3, n.1, p.22-41, 2006.

CASTRÉN, E. Is mood chemistry? Nat. Rev. Neurosci., v.6, n.3, p.241-46, 2005.

CONCEIÇÃO, I.M.; JURKIEWICZ, A.; FONSECA, D.R.; OPPERMAN, A.R.; FREITAS, T.A.; LEBRUN, I.; GARCEZ-DO-CARMO, L. Selective release of ATP from sympathetic nerves of rat vas deferens by the toxin TsTX-I from Brazilian scorpion Tityus serrulatus. Br. J. Pharmacol., v.144, n.4, p.519-27, 2005.

HASSANZADEH, P.; HASSANZADEH, A. Effects of psychotropic drugs on nerve growth factor protein levels in the rat brain. Physiol.-Pharmacol., v.13, n.3, p.244-52, 2009 .

KASUYA, Y.; GOTO, K.; HASHIMOTO, H.; WATANABE, H.; MUNAKATA, H.; WATANABE, M. Nonspecific denervation supersensitivity in the rat vas deferens "in vitro". Eur. J. Pharmacol., v.8, n.2, p.177-84, 1969.

KEAST, J.R.; KEPPER, M.E. Differential regulation of trkA and p75 in noradrenergic pelvic autonomic ganglion cells after deafferentation of their cholinergic neighbours. Eur. J. Neurosci., v.13, n.2, p.211-20, 2001.

KUIPERS, S.D.; BRAMHAM, C.R. Brain-derived neurotrophic factor mechanisms and function in adult synaptic plasticity: new insights and implications for therapy. Curr. Opin. Drug Discov. Devel., v.9, n.5, p.580-86, 2006.
MCALLISTER, A.K.; KATZ, L.C.; LO, D.C. Neurotrophins and synaptic plasticity. Annu. Rev. Neurosci., v.22, p.295318, 1999.

MILNER, P.; CROWE, R.; FERNYHOUGH, P.; DIEMEL, L.T.; TOMLINSON, D.R.; BURNSTOCK, G. Nerve growth factor treatment of adult rats selectively enhances innervation of urinogenital tract rather than vascular smooth muscle. Int. J. Dev. Neurosci., v.13, n.5, p.393-01, 1995.

MOLTENI, R.; CALABRESE, F.; BEDOGNI, F.; TONGIORGI, E.; FUMAGALLI, F.; RACAGNI, G.; RIVA, M.A. Chronic treatment with fluoxetine up-regulates cellular BDNF mRNA expression in rat dopaminergic regions. Int. J. Neuropsychopharmacol., v.9, n.3, p.307-17, 2006.

NESTLER, E.J.; BARROT, M.; DILEONE, R.J.; EISCH, A.J.; GOLD, S.J.; MONTEGGIA, L.M. Neurobiology of depression. Neuron, v.34, n.1, p.13-25, 2002.

NIBUYA, M.; NESTLER, E.J.; DUMAN, R.S. Chronic antidepressant administration increases the expression of cAMP response element binding protein (CREB) in rat hippocampus. J. Neurosci., v.16, n.7, p.2365-72, 1996.

RUSSO-NEUSTADT, A.A.; BEARD, R.C.; HUANG, Y.M.; COTMAN, C.W. Physical activity and antidepressant treatment potentiate the expression of specific brain-derived neurotrophic factor transcripts in the rat hippocampus. Neuroscience, v.101, n.2, p.305-12, 2000.

SANTARELLI, L.S.M.; GROSS, C.; SURGET, A.; BATTAGLIA, F.; DULAWA, S.; WEISSTAUB, N.; LEE, J.; DUMAN, R.; ARANCIO, O.; BELZUNG, C.; HEN, R. Requirement of hippocampal neurogenesis for the behavioral effects of antidepressants. Science, v.301, n.5634, p.805-809, 2003.

SANTOS, W.C.; SMAILI, S.S.; JURKIEWICZ, A.; PIÇARRO, I.; GARCEZ-DO-CARMO, L. Dual effect of agmatine in the bisected rat vas deferens. J. Pharm. Pharmacol., v.55, n.3, p.373-80, 2003.

SLATTERY, D.A.; HUDSON, A.L.; NUTT, D.J. Invited review: the evolution of antidepressant mechanisms. Fundam. Clin. Pharmacol., v.18, n.1, p.1-21, 2004.

SOFRONIEW, M.V.; HOWE, C.L.; MOBLEY, W.C. Nerve growth factor signaling, neuroprotection, and neural repair. Annu. Rev. Neurosci., v.24, p.1217-81, 2001. 
WANG, J.W.; DAVID, D.J.; MONCKTON, J.E.; BATTAGLIA, F.; HEN, R. Chronic fluoxetine stimulates maturation and synaptic plasticity of adult-born hippocampal granule cells. J. Neurosci., v.28, n.6, p.1374-84, 2008.
WANIGASEKARA, Y.; KEPPER, M.E.; KEAST, J.R. Immunohistochemical characterisation of pelvic autonomic ganglia in male mice. Cell. Tissue Res., v.311, n.2, p.175$85,2003$.

Received for publication on $06^{\text {th }}$ May 2013 Accepted for publication on $19^{\text {th }}$ November 2013 